\title{
Brand Trust as the Mediation Effect Customer Relationship Management on Customer Loyalty
}

\author{
Dewi Murtiningsih $^{1}$, Wendi Usino ${ }^{2}$, Darmawan Napitupulu ${ }^{3}$, A Adrianto ${ }^{4}$ \\ \{dewi.murtiningsih@budlihur.ac.id ${ }^{1}$,wendi.usino@budiluhur.ac.id ${ }^{2}$, darwan.na70@gmail.com³ \\ adrianto@ecampus.ut.ac.id $\left.{ }^{4}\right\}$ \\ ${ }^{1}$ Fakultas Ekonomi dan Bisnis, Universitas Budi Luhur, J1. Ciledug Raya, Jakarta, Indonesia \\ ${ }^{2}$ Fakultas Teknologi Informasi, Universitas Budi Luhur, Jl. Ciledug Raya, Jakarta, Indonesia \\ ${ }^{3}$ Pasca Sarjana, Universitas Budi Luhur, Jl. Ciledug Raya, Jakarta, Indonesia \\ ${ }^{4}$ Department of Management, Universitas Terbuka, Indonesia
}

\begin{abstract}
This study is aiming at determining the effect of customer relationship management on the customer loyalty, the effect of customer relationship management on brand trust, the effect of brand trust on customer loyalty and the mediating effect of brand trust on the relationship between customer relationship management and customer loyalty. This research is explanatory research with the population of undergraduate students (S1) in five faculties at Budi Luhur University, Jakarta who are at least sophomores. Data collected using questionnaire. The research sample is using purposive sampling with total of 110 respondents. The data were analyzed by path analysis using SPSS. Based on the results of research it can be seen that customer relationship management did not affect customer loyalty, customer relationship management did not affect brand trust, brand trust affected customer loyalty, and brand trust did not mediate the effect of customer relationship management to customer loyalty.
\end{abstract}

Keywords: Customer Relationship Management, Brand Trust, Customer Loyalty.

\section{Introduction}

One The rapid growth and development of private universities in Indonesia, especially in Jakarta, makes private universities implement the right business strategies in order to survive in the business world. Private universities should continually add new ways or breakthroughs in terms of interacting with their customers. In this case, "the customers of private universities" are students. Various strategies are applied in order to create competitive advantage so as to keep customers, in this case students. Customer relationship management is a strategy applied to be successful in facing competition and in creating loyalty.

Good relationships with consumers will make consumers loyal to company's products, and indirectly will do advertising through word of mouth, so that the future of the company becomes much more secure and better (Supriyadi, 2014). The company today not only needs to focus on adding new customers but also on how to keep the existing customers. This is reinforced by Shoemaker and Lewis in (Wijaya and Thio, 2008) that the cost of acquiring new buyers can be five times more expensive than the costs used to retain old customers.

According to (Tjiptono, 2000), customer loyalty is a customer commitment to a brand, store or supplier based on very positive nature in long-term purchases. Increasingly strict and hard competition conditions today have made customer loyalty an important thing that must be considered by every company in order to retain existing customers (Azizah, 2013). One of the efforts that can be done by company in maintaining customer loyalty is by improving customer experience and brand trust (Iskandar et al, 2011). Brand trust is a factor where a customer will be very confident in a brand sold by a company or retail (Sumardi and Soliha, 
E., 2015). Brand trust is closely related to customer loyalty because with the brand trust a customer will continue to consider and buy a product that has become its flagship. (Chaudhuri, et al., 2001) assess brand trust as a form of engagement process that has been fully assumed and deeply based (Dirbawanto, et al, 2016).

\section{Conceptual Framework and Hypothesis}

The According to Zethaml \& Bitner (2003) "relationship marketing (or relationship management) is a philosophy of doing business, a strategic orientation, that focuses on keeping and improving current customers rather than on acquiring new customers". Indicators of framework elements in the application of Customer Relationship Management according to (Peppers, D., Rogers, 2011) are: identity, differentiation, interaction, customize.

According to (Lau, G.T., 1999) brand trust is defined as customer's desire to rely on a brand on risks they face because expectations for the brand will lead to positive results. They stated that there are three factors that affect consumer's brand trust, namely; (1) Brand characteristic, (2) Company characteristic, (3) Consumer-brand characteristic.

The definition of customer loyalty according to (Oliver, 1996) is deeply held commitment to rebuy or patronize a preferred product or service consistently in the future, despite situational influences and marketing efforts having the potential to cause switching behavior". Loyal customers are important assets for a company. (Griffin, 2002) suggests four characteristics of loyal customers: makes regular repeat purchase; purchase across product and services lines; refers other; demonstrates immunity to the full of the competition.

The results of this research related to customer relationship management on customer loyalty which have been done by previous researchers namely Indah and (Indah, D P., Devie, 2013; Kartika, et al., 2011; Munandar, 2005) show that CRM has positive effects on customer loyalty. The research by Semuel (2012) shows that CRM has a positive effect on customer trust and loyalty. Based on the theory and the results of previous research, some hypotheses can be made as follows:

H1: customer relationship management has effect on customer loyalty.

$\mathrm{H} 2$ : customer relationship management has effect on brand trust.

$\mathrm{H} 3$ : brand trust has effect on customer loyalty.

H4: brand trust mediates the effect of customer relationship management on customer loyalty.

\section{Research Methodology}

This research is the explanatory research. The objects in this study, namely; (1) variables of customer relationship management, (2) brand trust and (3) customer loyalty. The subjects of this study are undergraduate students who are at least sophomores in five faculties at Budi Luhur University of Jakarta. The research sample is set at 100 plus $10 \%$, so the total sample is (n) 110 students. With consideration if there is a defect in collecting the remaining questionnaires, it will still meet the minimum rules of sample size. The analysis model used path analysis with SPSS.

\section{Result \& Discussions}

The results of research on the effect of customer relationship management on brand trust are as follows: 
Table 1. Coefficient of Effect of Customer Relationship Management to Brand Trust.

\begin{tabular}{|c|c|c|c|c|c|}
\hline \multirow{2}{*}{\multicolumn{2}{|c|}{ Model }} & $\begin{array}{l}\text { Unstandardize } \\
\text { d Coefficients }\end{array}$ & \multirow{2}{*}{$\begin{array}{l}\text { Standardiz } \\
\text { ed } \\
\text { Coefficient } \\
\text { s } \\
\text { Std. Error }\end{array}$} & \multirow{2}{*}{$\begin{array}{l}\mathrm{t} \\
\text { Beta }\end{array}$} & \multirow[t]{2}{*}{ Sig. } \\
\hline & & B & & & \\
\hline $1 \quad$ (Constant) & \multirow{3}{*}{ Relationship } & 11.05 & & 11.732 & .000 \\
\hline Customer & & 0 & & & \\
\hline Management & & -.009 & -.013 & -.132 & .895 \\
\hline
\end{tabular}

Based on the data Table 1 above, it can be seen that customer relationship management does not affect the brand trust due to the sig value. (0.895) is greater than p-value $(0.05)$. This study is in contrast to research conducted by Semuel (2012) who shows that CRM has a positive effect on trust.

As for the effect of customer relationship management and brand trust on customer loyalty, is shown in table below:

Table 2.Coefficient of Effect of Customer Relationship Management and Brand Trust on Customer Loyalty.

\begin{tabular}{llrrrrr}
\hline \multirow{2}{*}{ Model } & \multicolumn{2}{c}{$\begin{array}{c}\text { Unstandardized } \\
\text { Coefficients }\end{array}$} & $\begin{array}{c}\text { Standardized } \\
\text { Coefficients }\end{array}$ & $\mathrm{t}$ & Sig. \\
\cline { 2 - 7 } & \multicolumn{1}{c}{$\mathrm{B}$} & Std. Error & Beta & & \\
\hline 1 & (Constant) & 11.387 & 1.725 & & 6.603 & .000 \\
\hline & $\begin{array}{l}\text { Customer Relationship } \\
\text { Management }\end{array}$ & -.021 & .084 & -.023 & -.250 & .803 \\
\hline Brand Trust & .304 & .117 & .244 & 2.601 & .011 \\
\hline
\end{tabular}

Based on Table 2 above, the customer relationship management does not affect the customer loyalty, this research is in contrast to research conducted by (Indah, D P., Devie, 2013; Kartika, et al., 2011; Munandar, 2005) show that customer relationship management has positive effect on customer loyalty while brand trust has effect customer loyalty.

To know the mediating effect of brand trust variable on the relationship between customer relationship management and customer loyalty, soberly test obtained value Z ($0.0076)<1.96$, because $t$-value is smaller than T-table value so it can be said that there is no mediating effect, which has meaning that brand trust does not mediate the effect of customer relationship management on customer loyalty.

\section{Conclusion}

Based on the results of the discussion above, specifically, the conclusions of the research can be put forward as follows: customer relationship management is not able to affect the increase of customer loyalty directly. Customer relationship management is not able to affect the increase of brand trust. Higher brand trust is able to affect the increase of customer loyalty. Brand trust does not play a role in mediating the effect of customer relationship management on customer loyalty. 


\section{Acknowledgements}

We would like to thank the research institution that has supported the research activities was being carried out properly.

\section{Reference}

[1] Azizah, 2013. Pengaruh Kualitas Layanan, Citra Dan Kepuasan Terhadap Loyalitas Nasabah. Manag. Anal. J. 1(2).

[2] Chaudhuri, et al., 2001. The Chain of Effects from brand Trust and Brand affect to Brand Performance: The Role of Brand Loyalty. J. Mark. 65, 81-93.

[3] Dirbawanto, et al, ., 2016. Pengaruh Customer Experience dan Brand Trust terhadap Customer Loyalty. Manag. Anal. J. 5 (1).

[4] Griffin, J., 2002. Customer Loyalty How to Earn it, How to Keep it. Lexington Books, Singapore.

[5] Indah, D P., Devie, 2013. Analisa Pengaruh Customer Relationship Management Terhadap Keunggulan Bersaing Dan Kinerja Perusahaan. J. Bus. Account. Rev. 1(2).

[6] Iskandar, et al., 2011. Analisis Pengaruh Customer Experience Management Terhadap Brand Trust dan Dampakanya Terhadap Customer Loyalty Marielle Skin Care., in: Jurnal Pemasaran. FE Universitas Bina Nusantara, Jakarta.

[7] Kartika, et al., 2011. Pengaruh Customer Relationship Management terhadap Loyalitas Pelanggan pada PT.BCA, Tbk. J. Manaj. Pemasar. 10(3).

[8] Lau, G.T., L.S.H., 1999. Consumers Trust In a Brand and The Link To Brand Loyalty. J. Mark. Focus. Manag. 4, 341-370.

[9] Munandar, D., 2005. Pengaruh Customer Relationship Management Terhadap Loyalitas Pelanggan Bisnis PT. Frisian Flag Indonesia. Maj. Ilm. UNIKOM.

[10] Oliver, R., 1996. Satisfaction a Behaviour Perspective on The Customer. McGrawHill, New York.

[11] Peppers, D., Rogers, M., 2011. Managing Customer Relationships: A Strategic Framework Second Edition. John Wiley \& Sons, Inc., New Jersey.

[12] Sumardi and Soliha, E., 2015. The Effect of Bank Image and Trust on Loyality Mediated by Customer Satisfaction. J. Din. Manaj. 6(2).

[13] Supriyadi, et al., 2014. Customer Relationship Management dan Loyalitas Konsumen Pada PT Shafira laras Perdasa. SMART-Study Manag. Res. 11(2), 1-9.

[14] Tjiptono, F., 2000. Perspektif Manajemen \& Pemasaran Kontemporer. Andi, Yogyakarta.

[15] Wijaya, S., and Thio, s., 2008. Implementasi Membership Card dan Pengaruhnya dalam Meningkatkan Loyalitas Pengunjung Restoran di Surabaya. 